\title{
Prevalence of hepatitis C virus infection and HCV genotypes among hemophiliacs in the State of Bahia, Northeastern Brazil: analysis of serological and virological parameters
}

\author{
Prevalência da infecção pelo vírus da hepatite $C$ e genótipos \\ entre hemofílicos no Estado da Bahia, nordeste do Brasil: \\ análise de parâmetros sorológicos e virológicos
}

\author{
Luciano Kalabric Silva ${ }^{1}$, Maria Betânia Souza da Silva ${ }^{1}$, Gisele Barreto Lopes ${ }^{1}$, \\ Itatiana Ferreira Rodart ${ }^{1}$, Fernando Quadros Costa ${ }^{1}$, Nelma P. Santana ${ }^{2}$, Raymundo Paraná ${ }^{3}$, \\ Aurelino Santana ${ }^{4}$ and Mitermayer Galvão dos Reis ${ }^{1,3,4}$
}

\begin{abstract}
The objective of the present study was to analyze HCV serological and virological parameters from hemophiliacs in the State of Bahia. Anti-HCV was investigated by ELISA in a cohort of 268 hemophiliacs A/B who were followed-up in a reference unit for hemotherapy in the State of Bahia. HCV viremia and genotypes were also determined from a subset of 66 anti-HCV seropositive hemophiliacs. Seroprevalence among hemophiliacs was 42.2\% (95\% CI 36.5-48.1) and was significantly higher ( $<<0.05)$ according to age $\geq 10$ years, presence of factor VIII/IX inhibitory antibodies and other infection markers. None of the hemophiliacs less than 5 years of age were anti-HCV seropositive. Viremia was detectable in 77.3\% (51/66). HCV genotype 1 (74\%) was the most prevalent followed by genotype 3 (22\%) and genotype 2 (4\%). Our results indicate that HCV prevalence is still high among hemophiliacs, although HCV transmission was not observed in young hemophiliacs.
\end{abstract}

Key-words: Hepatitis C virus. Hemophilia. Prevalence. Genotype. Bahia.

\section{RESUMO}

O objetivo deste estudo foi analisar parâmetros sorológicos e virológicos em hemofílicos no Estado da Bahia. O anti-VHC foi investigado por ELISA em uma coorte de 268 hemofílicos A/B sob acompanhamento em uma unidade de referência do Estado da Bahia. A viremia do VHC e genótipos foram determinados em um subgrupo de 66 hemofílicos soropositivos para o antiVHC. A soroprevalência do anti-VHC entre os hemofílicos foi de 42,2\% (IC 95\% 36,5-48,1) e foi associada significativamente $(p<0,05)$ a idade $\geq 10$ anos, presença de anticorpos antifator VIII/IX e outros marcadores sorológicos de infecção. Nenhum dos hemofílicos com idade inferior a 5 anos foram anti-VHC positivos. A viremia foi detectada em 77,3\% (51/66), sendo o genótipo 1 do VHC (74\%) o mais prevalente, seguido pelos genótipos 3 (22\%) e 2 (4\%). Nossos resultados indicam que a prevalência do VHC é ainda alta entre os hemofílicos, muito embora a transmissão não tenha sido observada entre os menores de 5 anos.

Palavras-chaves: Vírus da hepatite C. Hemofilia. Prevalência. Genótipos. Bahia.

\footnotetext{
1. Laboratory of Pathology and Molecular Biology, Gonçalo Moniz Research Center, Fundação Oswaldo Cruz, Salvador, BA, Brazil. 2. Hemotransfusion and Hemotherapy Foundation (HEMOBA), Secretaria de Saúde do Estado da Bahia, Salvador, BA, Brazil. 3. School of Medicine, Universidade Federal da Bahia, Salvador, BA, Brazil. 4. School of Medicine and Public Health, FDC, Salvador, BA, Brazil.

Informed consent was obtained from all subjects who participated in this study. Guidelines of the Ethical Committee of the Gonçalo Moniz Research Center, FIOCRUZ, were followed in the conduct of this research.

Financial support: This work was partially supported by research grants from CNPq, FIOCRUZ, FAPESB, and CAPES/FIOCRUZ (doctorate scholarship, between March 1999 to March 2003).

Address to: Prof. Mitermayer G. Reis. Centro de Pesquisas Gonçalo Moniz/FIOCRUZ. R. Waldemar Falcão 121, Brotas, 40295-001 Salvador-BA, Brasil.

Tel: 5571 3356-4320; ext: 205; Fax: 5571 3356-4292.

e-mail: miter@cpqgm.fiocruz.br

Recebido para publicação em 28/9/2004

Aceito em 20/8/2005
} 
Hepatitis C virus (HCV), a positive-stranded RNA virus, has been identified as the major causative agent of non-A non-B post transfusion hepatitis ${ }^{817}$. Prior to the introduction of screening candidate blood donors for antibody to hepatitis $\mathrm{C}$ virus (anti-HCV) and inactivation methods for pooled plasma products, nearly all hemophiliacs became infected with HCV soon after their first exposure ${ }^{23}$. In the early 1990s, data from around the world showed that the seroprevalence of anti-HCV antibodies in hemophiliacs could reach up to $90 \%{ }^{112126314748}$, because virtually all clotting factor concentrates manufactured before the late 1980s were contaminated $^{22}$. As a consequence, HCV is by far the most common cause of infection among hemophiliacs.

Since the mid 1970s, with evidence of the existence of non-A non-B hepatitis viruses and the early 1980 s with the epidemic of human immunodeficiency virus (HIV), physicians involved in hemophiliac care and manufacturers of clotting factors have been aware of the risk of transmission of unknown viruses ${ }^{12} 1315$. Consequently, methods have been developed to inactivate these viruses, which became accessible in the developed countries in the mid 1980s. It is now known that some of these methods such as pasteurization in liquid state $\left(10 \mathrm{hr}\right.$ at $\left.60^{\circ} \mathrm{C}\right)$, viral inactivation by the so-called solvent detergent (SD) and dry heat treatment up to $80^{\circ} \mathrm{C}$ were effective, while others were inappropriate ${ }^{91415303241}$. Other risk factors for HCV infection in hemophiliacs include age, severity of disease, previous blood transfusion, annual quantity of clotting factor and infection with human immunodeficiency virus (HIV) $)^{634}$.

In the majority of the developing countries, these inactivated products were introduced only in the mid 1990s, substituting locally produced cryoprecipitate and fresh-frozen plasma. In Brazil, seroprevalence of HCV infection in hemophiliacs can range from $44.6 \%$ to $60 \%$ according to studies conducted in Southeastern and Central areas of Brazil ${ }^{62434}$. Carmo et $\mathrm{al}^{6}$ published a follow-up study from the State of Minas Gerais, Southeastern Brazil, revealing a tendency towards a decrease in the general seroprevalence of HCV infection among hemophiliacs. However, the majority of seropositive hemophiliacs identified were viremic, indicating the necessity of specialized health care and treatment.

The study of the genetic variability of HCV strains have led to a consensus classification of six major genotypes, many of which include a number of closely related subtypes ${ }^{74}$. Studies suggest that the clinical features of liver disease depend on HCV genotypes ${ }^{203342} 49$. It is also noteworthy that the success of interferon treatment seems to be genotype related $^{16}$. These observations make the identification of infecting HCV genotypes from different geographical regions and groups under risk of great interest. Furthermore, genotypes can be a very useful tool for molecular epidemiology purposes.

Thus, the primary objective of the present study was to determine the hepatitis $\mathrm{C}$ virus (HCV) seroprevalence, viremia and genotypes isolated from a cohort of hemophiliacs in the State of Bahia, Northeastern Brazil.

\section{PATIENTS AND METHODS}

Patients. Between November 1999 and August 2000, the Hemotransfusion and Hemotherapy Foundation of Bahia (HEMOBA) attended a total of 339 patients with hemophilia A or B. However only 268 were tested in HEMOBA for the presence of anti-HCV by ELISA ( $3^{\text {rd }}$ Generation, Abbott Murex, IL, USA) and became eligible for the study.

Laboratory data. Clinical and laboratory data were collected from patients' records and are summarized in Table 1. Serological tests for anti-HCV (Abbott Murex, IL, USA), HBsAg/ anti-HBc (Biorad, CA, USA), anti-HIV (Biorad, CA, USA), antiHTLV I/II (Abbott Murex, IL, USA), Chagas' disease (Embrabio, SP, Brazil) and Syphilis (Weiner Lab, Argentine) were based on ELISA according to each manufacturer's instructions. To test the coagulation factors and the presence of inhibitor antibody activity, the functional method based on the comparative activity assays against a factor deficient plasma was used according to the kit instructions (Biomérieux, NC, USA).

Samples for molecular assays. Of the total of anti-HCV positive hemophiliacs, only 66 patients returned to HEMOBA to receive treatment during the period of this study and were interviewed and had their serum collected for molecular assays. The Institution Ethical Committee approved this study and informed consent was obtained from all subjects enrolled in the study. Within 2 hours after venopuncture all samples were aliquoted and stored immediately at $-70^{\circ} \mathrm{C}$ until use. Aliquots were not thawed more than once prior to analysis.

Extraction of HCV RNA and cDNA synthesis. Two hundred microliters of serum were used for HCV RNA extraction using Trizol LS reagent (Invitrogen Life Technologies, CA, USA) following the manufacturer's instructions and were precipitated with ethanol and then dried $^{36}$. HCV RNA was immediately transcribed into cDNA using random primers (Amersham Biosciences, NJ, USA). Samples with HCV RNA undetectable by nested-PCR described below were extracted twice in different experiments. Even if they were confirmed negative, all these patients were recalled to repeat the blood collection within six months after the first examination in order to avoid false negative results.

HCV RNA detection and genotyping. cDNA was targeted by a nested-PCR directed to the 5'UTR using specific primers 939, 209, 940 and 211 as described previously ${ }^{7}$. The size of the nestedPCR product was $251 \mathrm{bp}$. Positivity was confirmed by identification of this fragment after electrophoresis on a $1.5 \%$ routine agarose gel and ethidium bromide staining under UV light. Positive samples were genotyped by RFLP ${ }^{10}{ }^{28}$. Briefly, restriction digests were carried out on the $251 \mathrm{bp}$ PCR products for 4-16h after adjustment with 10x enzyme reaction buffer as appropriate. Reactions were at $37^{\circ} \mathrm{C}$ in the presence of 10 units each of (a) RsaI and HaeIII, and (b) Hinfl and MvaI. Digestion products were visualized under UV light after electrophoresis through a $4 \%$ Metaphor agarose gel (BMA, ME, USA) in $1 \times$ Tris-borate buffer containing $0.5 \mathrm{mg} / \mathrm{ml}$ ethidium bromide. Figure 1 illustrates the band pattern consistently produced by RFLP in different genotypes. Genotypes were determined according to Simmond's classification ${ }^{44}$. 


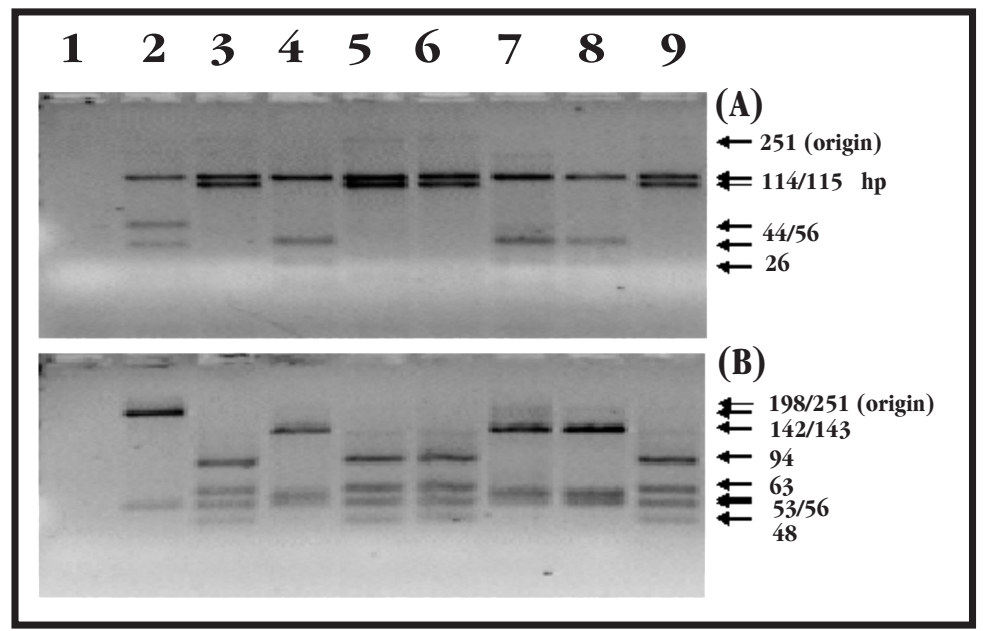

Figure 1- Electrophoresis through a 4\% Metaphor agarose of restriction digests carried out on the $251 \mathrm{bp} \mathrm{PCR}$ fragment. Reactions were at $37^{\circ} \mathrm{C}$ in the presence of 10 units each of (A) Rsal and HaelII, (B) Hinfl and Mval as described by McOmish et $\mathrm{a}^{28}$ and Davidson et al ${ }^{1028}$. Lane 1 - blank control; lane 2 - genotype 2 control; lane 3 - genotype 1 control; lane 4 - genotype 3 control; lanes 5, 6, 9 genotype 1 samples and lanes 7,8 - genotype 3 samples. Genotype was deduced from the banding patterns produced by the two restriction enzyme combinations.

Statistical analysis. Data were entered into two statistical database packages: Epi Info 6.04d (Center for Disease Control, GA, USA) and SPSS v 10 (IL, USA). Estimates for $95 \%$ confidence intervals ( $95 \% \mathrm{CI}$ ) of prevalence were calculated using the Mid-p algorithmic. Fisher's exact test and $\chi^{2}$ test (Yates corrected) were used to compare frequencies between groups when appropriate. ANOVA was used to compare means or Kruskal-Wallis test when the variances were heterogeneous. In all tests, $\mathrm{p}$ values $<0.05$ were considered statistically significant.

\section{RESULTS}

Baseline characteristics of the 268 hemophiliacs participating in this study are shown in Table 1 . The mean age for all hemophiliacs was $19.5 \pm 12.1$ years old, age range from $<1$ to 66 years old, $238(88.8 \%)$ were hemophilia A and $30(11.2 \%)$ were hemophilia $B$, most live in the interior of the State $(66.8 \%)$, the severity of disease was predominately mild to moderate $(89.6 \%)$ and there was a high prevalence of factor VIII/IX inhibitory antibodies $(35.7 \%)$.

of the 268 hemophiliacs, 113 were found to be anti-HCV antibody positive resulting in an overall seroprevalence of 42.2\% (95\% CI 36.5-48.1). Other serological markers were also determined: HBV in $22.5 \%$, HIV in $10.4 \%$, HTLV I/II in $3.7 \%$, Chagas' disease in $4.1 \%$ and syphilis in $1.1 \%$. Almost half of the patients (128) presented at least one marker and $50 \%(64 / 128)$ of these presented multiple markers.

Seroprevalence for anti-HCV according to age is presented in Figure 2. Seroprevalence decreased significantly during the last decade. There were no seropositive cases among hemophiliacs younger than 5 years old. By bivariate analysis, anti-HCV antibody positivity was associated with age older than 10 years, residence in Salvador, the capital of the State,
Table 1 - Baseline characteristics of hemophiliacs participating in this study.

\begin{tabular}{|c|c|c|c|}
\hline \multirow[b]{2}{*}{ Characteristics } & \multicolumn{2}{|c|}{ Type of disease } & \multirow[b]{2}{*}{$\begin{array}{c}\text { Total } \\
\mathrm{n}^{\mathrm{o}}(\%)^{\S}\end{array}$} \\
\hline & $\begin{array}{c}\text { hemophilia A } \\
n^{\circ}=238(88.8 \%)\end{array}$ & $\begin{array}{c}\text { hemophilia B } \\
\mathrm{n}^{0}=30(11.2 \%)\end{array}$ & \\
\hline \multicolumn{4}{|l|}{ Age (yr) } \\
\hline mean $\pm \sigma$ & $19.6 \pm 12.3$ & $18.5 \pm 11.1$ & $19.5 \pm 12.1$ \\
\hline range & $<1-66$ & $2-40$ & $<1-66$ \\
\hline \multicolumn{4}{|l|}{ Residence } \\
\hline capital & $79(33.2)$ & $10(33.3)$ & $89(33.2)$ \\
\hline other cities & $159(66.8)$ & $20(66.7)$ & $179(66.8)$ \\
\hline \multicolumn{4}{|l|}{ Severity of disease } \\
\hline severe $(<1 \%)$ & $18(10.5)$ & $2(9.1)$ & $20(10.4)$ \\
\hline mild/moderate $(\geq 1 \%)$ & $153(89.5)$ & $20(90.9)$ & $173(89.6)$ \\
\hline \multicolumn{4}{|c|}{ Factor VIII/IX inhibitory antibodies } \\
\hline present & $15(41.7)$ & $0(0)$ & $15(35.7)$ \\
\hline absent & $21(58.3)$ & $6(100)$ & $27(64.3)$ \\
\hline \multicolumn{4}{|l|}{ Seropositivity } \\
\hline anti-HCV & $105(44.1)$ & $8(26.7)$ & $113(42.2)$ \\
\hline AgHBs/anti-HBc & $53(22.3)$ & $7(23.3)$ & $60(22.5)$ \\
\hline anti-HIV & $24(10.1)$ & $4(13.3)$ & $28(10.4)$ \\
\hline anti-HTLV I/II & $10(4.2)$ & $0(0)$ & $10(3.7)$ \\
\hline Chagas' disease & $9(3.8)$ & $2(6.7)$ & $11(4.1)$ \\
\hline syphilis & $2(0.8)$ & $1(3.3)$ & $3(1.1)$ \\
\hline
\end{tabular}

$\S$ Totals vary according to the availability of data.

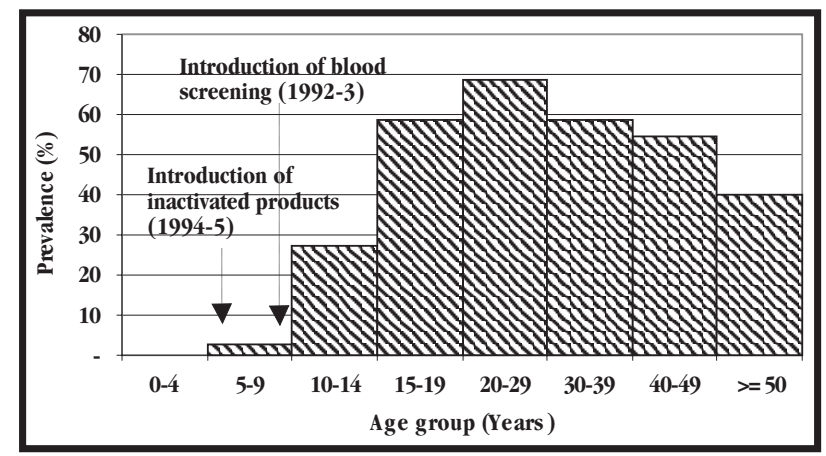

Figure 2 - Seroprevalence of anti-HCV antibody according to age in hemophiliacs in the State of Bahia, northeastern Brazil, 2000. 
presence of inhibitory antibodies, and positivity to HBV, HIV, HTLV-I/II and Chagas' disease (T. cruzi infection) but not with the type of hemophilia, the severity of the disease or positivity to syphilis (Table 2).

From a subset of 66 hemophiliacs, HCV-RNA could be detected in $77.3 \%(51 / 66)$. The prevalence of HCV infection confirmed by the detection of HCV-RNA in hemophiliacs in Salvador is therefore estimated to be $32.6 \%$ (95\% CI 24.342.6). However, this sample may not be representative, since the presence of HCV-RNA could not confirm any of the associations with potential risk factors found for anti-HCV+ hemophiliacs (Table 2).

Specimens from 50 hemophiliacs could be genotyped. Despite several attempts, one sample from a hemophilia patient could not be genotyped successfully. The distribution of HCV genotypes is shown in Table 3. HCV genotype distribution was similar to the distribution from local candidate blood donors (data not shown), with predominance of genotype 1 (74\%), followed by genotype 3 (22\%) and the rare genotype 2 (4\%). As for viremia, the genotype could not be associated with any of the characteristics analyzed previously (Table 4).

Table 2 - Potential risk factors associated with the prevalence of anti-HCV and viremia of hemophiliacs in Salvador, BA, Brazil.

\begin{tabular}{|c|c|c|c|c|c|c|c|c|}
\hline \multirow[t]{2}{*}{ Characteristics } & \multicolumn{4}{|c|}{ anti-HCV antibodies positivity } & \multicolumn{4}{|c|}{ HCV-RNA detectable } \\
\hline & $\mathrm{n}^{\mathrm{o}}$ tested $\mathrm{d}^{\S}$ & $\%$ positive & OR $(95 \% \mathrm{CI})$ & $\mathrm{p}$ values & $\mathrm{n}^{0}$ tested ${ }^{\S}$ & $\%$ detectable & OR $(95 \% \mathrm{CI})$ & $\mathrm{p}$ values \\
\hline All subjects & 268 & 42.2 & - & - & 66 & 77.3 & - & - \\
\hline \multicolumn{9}{|l|}{ Age, years } \\
\hline$\geq 10$ & 198 & 56.1 & $43.48(9.94-266.79)$ & $<0.01$ & 65 & 78.5 & $7.43(0.47-224.72)^{¥}$ & NS \\
\hline$<10 \dagger$ & 70 & 2.9 & 1.00 & & 1 & 0.0 & 1.00 & \\
\hline \multicolumn{9}{|l|}{ Residence } \\
\hline capital & 89 & 59.6 & $2.92(1.73-4.94)$ & $<0.01$ & 38 & 76.3 & $0.88(0.23-3.30)$ & NS \\
\hline other cities $\dagger$ & 179 & 33.5 & 1.00 & & 28 & 78.6 & 1.00 & \\
\hline \multicolumn{9}{|l|}{ Type of disease } \\
\hline hemophilia A & 238 & 44.1 & $2.17(0.93-5.07)$ & NS & 60 & 78.3 & $1.81(0.20-13.90)$ & NS \\
\hline hemophilia $\mathrm{B} \dagger$ & 30 & 26.7 & 1.00 & & 6 & 66.7 & 1.00 & \\
\hline \multicolumn{9}{|l|}{ Severity of hemophilia } \\
\hline severe $(<1 \%)$ & 20 & 55.0 & $2.36(0.85-6.62)$ & NS & 6 & 66.7 & $0.47(0.05-4.60)$ & NS \\
\hline mild/moderate $(\geq 1 \%) \dagger$ & $\dagger 173$ & 34.1 & 1.00 & & 37 & 81.1 & 1.00 & \\
\hline \multicolumn{9}{|c|}{ Inhibitory antibodies } \\
\hline present & 15 & 60.0 & $4.29(0.93-20.88)$ & $0.06 \ddagger$ & 7 & 85.7 & $4.00(0.15-186.31)$ & NS \\
\hline absent $\dagger$ & 27 & 25.9 & 1.00 & & 5 & 60.0 & 1.00 & \\
\hline \multicolumn{9}{|l|}{ Other viral markers } \\
\hline AgHBs/anti-HBc positive & 60 & 81.7 & $9.95(4.60-21.97)$ & 0.01 & 28 & 85.7 & $2.44(0.59-10.75$ & NS \\
\hline negative $\dagger$ & 207 & 30.9 & 1.00 & & 38 & 71.1 & 1.00 & \\
\hline anti-HIV positive & 28 & 85.7 & $10.18(3.18-36.24)$ & $<0.019$ & 15 & 80.0 & $0.81(0.15-3.95)$ & NS \\
\hline negative $\dagger$ & 240 & 37.1 & 1.00 & & 51 & 76.5 & 1.00 & \\
\hline anti-HTLV I/II positive & 10 & 100.0 & $16.50(2.16-347.00)^{¥}$ & $<0.01$ व & 7 & 71.4 & $0.71(0.10-6.08)$ & NS \\
\hline negative $\dagger$ & 258 & 39.9 & 1.00 & & 59 & 78.0 & 1.00 & \\
\hline
\end{tabular}

$\mathrm{OR}=$ odds ratio and CI confidence interval. †Subjects in this category served as reference group. $§$ Totals vary according to the availability of data. $\ddagger$ Inhibitory antibodies were significantly associated with anti-HCV positivity by Mantel-Haenszel. ¥0R was estimated by adding 1 in each cell. $q$ Fisher e-test.

Table 3 - Prevalence of HCV genotypes in hemophiliacs in State of Bahia, Northeastern Brazil.

\begin{tabular}{lcccc}
\hline \multicolumn{4}{c}{ № (\%) of isolates of the genotype } \\
\hline Exposure category & All & Type 1 & Type 2 & Type 3 \\
Hemophiliacs & $50(100.0)$ & $37(74.0)$ & $2(4.0)$ & $11(22.0)$ \\
\hline Note: Genotyping by RFLP analysis of the PCR product from the 5'UTR as described previously ${ }^{1028}$ &
\end{tabular}

Note: Genotyping by RFLP analysis of the PCR product from the 5'UTR as described previously ${ }^{10} 28$

Table 4 - HCV genotype and potential risk factors in hemophiliacs in Salvador-BA, Brazil.

\begin{tabular}{|c|c|c|c|c|c|}
\hline \multirow[b]{2}{*}{ Characteristics } & \multicolumn{4}{|c|}{ HCV genotypes } & \multirow[b]{2}{*}{$\mathrm{p}$ values } \\
\hline & № tested $\$$ & Type 1 & Type not-1 & OR $(95 \% \mathrm{CI})$ & \\
\hline All subjects & 50 & $37(74.0)$ & $13(26.0)$ & - & - \\
\hline \multicolumn{6}{|l|}{ Age, years } \\
\hline$\geq 10$ & 50 & $37(74.0)$ & $13(26.0)$ & undefined & NS \\
\hline$<10 \dagger$ & 0 & & & & \\
\hline \multicolumn{6}{|l|}{ Residence } \\
\hline capital & 28 & $20(71.4)$ & $8(28.6)$ & $0.74(0.16-3.20)$ & NS \\
\hline other cities $\dagger$ & 22 & $17(77.3)$ & $5(22.7)$ & 1.00 & \\
\hline
\end{tabular}




\begin{tabular}{|c|c|c|c|c|c|}
\hline \multirow[b]{2}{*}{ Characteristics } & \multicolumn{4}{|c|}{ HCV genotypes } & \multirow[b]{2}{*}{$\mathrm{p}$ values } \\
\hline & No tested ${ }^{\S}$ & Type 1 & Type not-1 & OR $(95 \% \mathrm{CI})$ & \\
\hline \multicolumn{6}{|l|}{ Type of disease } \\
\hline hemophilia A & 46 & $35(76.1)$ & $11(23.9)$ & $3.18(0.27-37.96)$ & NSף \\
\hline hemophilia $\mathrm{B} \dagger$ & 4 & $2(50.0)$ & $2(50.0)$ & 1.00 & \\
\hline \multicolumn{6}{|l|}{ Severity of hemophilia } \\
\hline severe $(<1 \%)$ & 5 & $4(80.0)$ & $1(20.0)$ & $1.33(0.10-37.59)$ & NSף \\
\hline mild/moderate $(\geq 1 \%) \dagger$ & 28 & $21(75.0)$ & $7(25.0)$ & 1.00 & \\
\hline \multicolumn{6}{|l|}{ Inhibitory antibodies } \\
\hline present & 5 & $4(80.0)$ & $1(20.0)$ & $8.00(0.16-1,826.20)$ & NSף \\
\hline absent $\dagger$ & 3 & $1(33.3)$ & $2(66.7)$ & 1.00 & \\
\hline \multicolumn{6}{|l|}{ Other viral markers } \\
\hline AgHBs/anti-HBc positive & 25 & $20(80.0)$ & $5(20.0)$ & $1.88(0.43-8.42)$ & NS \\
\hline negative $\dagger$ & 25 & $17(68.0)$ & $8(32.0)$ & 1.00 & \\
\hline anti-HIV positive & 12 & $8(66.7)$ & $4(33.3)$ & $0.62(0.12-3.23)$ & NSף \\
\hline negative $†$ & 38 & $29(76.3)$ & $9(23.7)$ & 1.00 & \\
\hline anti-HTLV I/II positive & 4 & $4(100.0)$ & $0(0.0)$ & $1.97(0.19-48.99)^{¥}$ & NSף \\
\hline negative $\dagger$ & 46 & $33(71.7)$ & $13(28.3)$ & 1.00 & \\
\hline
\end{tabular}

$\mathrm{OR}=$ odds ratio and CI confidence interval. $†$ Subjects in this category served as reference group. $\S$ Totals vary according to the availability of data. $¥ 0 \mathrm{R}$ was estimated by adding 1 in each cell. ๆFisher e-test.

\section{DISCUSSION}

The overall prevalence of anti-HCV in our population of hemophiliacs (42.2\%) was similar to other studies performed in different regions of Brazil ${ }^{4634}$. However, because most of our patients were also infected with HIV and HTLV I/II, it cannot be excluded that the detection rate of anti-HCV in this group may underestimate the real seroprevalence, as has been demonstrated previously ${ }^{18}$.

With the use of HCV-safe clotting products and the introduction of screening tests in the blood banks, there is a very important tendency towards decrease of seropositivity for anti-HCV antibodies among hemophiliac patients in Brazil and other countries ${ }^{4632}$. In our study, HCV seroprevalence among hemophiliacs younger than 10 years old was quite similar to that found among candidate blood donors screened at HEMOBA (1.5\%, personal communication) during the same period of time. However, it will need another five to ten years to confirm that young hemophiliacs are really protected from HCV infection.

Residence in Salvador, the state capital, was shown to be an independent risk factor for acquiring HCV but not for developing chronic infection. This association may be particularly influenced by age, access to the service, time of residence in the city and other confounding factors (data not shown), and more exploratory analysis is necessary. Although the risk of HCV infection from environmental exposure (not related to transfusion of blood or derivates) is low, it is not altogether absent. In Bahia, Silva et al (1995) studied the seroprevalence of anti-HCV in urban and rural populations and demonstrated that HCV was 1.5\% prevalent in Salvador and absent in a city of the interior. This data suggests that HCV can be an endemic urban disease.

Even though the detection of anti-HCV could be used as a part of this study, these results should be interpreted with some care. Anti-HCV antibodies were associated with serological markers for other blood-borne infections (HBV, HIV and HTLV-I/II). These findings surely reflect the similar modes of transmission. However, it is still unclear whether HIV infection can interfere negatively by immune-suppression of some individuals, which could increase the uncertainty of our results and lead to underestimation of the prevalence ${ }^{6}$. Some investigators have reported HCV seronegative candidate blood donors or patients that were HCV-RNA positive by PCR, specially when associated with HIV and low CD4 cells counts $\left(<200 \times 10^{9} / 1\right)^{34345}$. On the other hand, the possibility of false positive results caused by unspecific reactions by the kits cannot be excluded. Therefore, HCV viremia and genotyping were also investigated in hemophiliacs.

HCV-RNA could be detected in the majority of anti-HCV positive hemophiliacs (77.3\%) which is compatible to the chronicity rates reported for this infection ${ }^{2}$. Hence, about $20 \%$ of HCV-infected hemophiliacs seem to have resolved HCV infection. It cannot be ruled out that some hemophiliacs have viral replication below the detection limit of polymerase chain reaction (PCR). To increase the sensitivity of PCR some authors have suggested the application of the PCR to detect HCV viremia in whole blood instead of in serum $^{27} 3940$. Furthermore, a new promising methodology base on transcription-mediated amplification has become available for more accurate HCV-RNA detection ${ }^{37} 38$.

While certain risk factors could be identified for anti-HCV hemophiliacs in Salvador, no significant association could be linked to the presence of HCV-RNA in serum or the HCV genotypes. Some studies have reported that HCV viremia was associated with older age and abnormal ALT levels, while the presence of inhibitory antibodies and HBsAg were protective factors against the detection of HCV-RNA. The mechanisms for this have been not explained ${ }^{6}$, and we have not found significant evidence in favor.

In our study, HCV genotype 1 was most frequent (74\%), followed by genotype $3(22 \%)$ and genotype 2 (4\%). Although heterotypic superinfection and mixed infections of hepatitis 
C virus may be possible ${ }^{46}$, the distribution of HCV genotypes among the hemophiliacs was similar to the candidate blood donors (data not shown). Similar results have already been reported for other regions in Brazil in the same exposure group ${ }^{4525}$. Considering the dynamic behavior of HCV infection, a study has shown that a phenomenon of HCV superinfection and overgrowth can occur in chronically infected patients and suggests that HCV genotypes $1 \mathrm{a}$ and $1 \mathrm{~b}$ may possess replicative advantages over other genotypes ${ }^{19}$. However, this has not been confirmed experimentally ${ }^{29}$. It is therefore probable that the high prevalence of $\mathrm{HCV}$ genotype 1 in this population reflects the origin of the blood and derivates.

It was not possible to study all the hemophiliacs in this region, which would have enabled us to draw firm conclusions. However, these findings clarify the status of HCV infection in hemophiliacs from a northeastern area of Brazil, and highlight the importance of studying the HCV genotypes due to their relevance in the management of patients under interferon therapy. Special consideration has to be taken since most of our patients are infected by HCV genotype 1 and are co-infected with HIV, which can lead to more rapidly developing progressive liver disease in infected hemophiliacs ${ }^{135}$. Therefore, this study demonstrates that hemophiliacs are a group at high risk for severe chronic hepatitis $\mathrm{C}$ disease in Bahia and will require hepatological assistance and longer antiviral therapy.

\section{ACKNOWLEDGMENTS}

We thank the patients for compliance in participating in this study, the Associação Bahiana dos Hemofílicos, and the staff from Hemotransfusion and Hemotherapy Foundation (HEMOBA/ SESAB) for efficient assistance during the field surveys.

\section{REFERENCES}

1. Allain JP, Dailey SH, Laurian Y, Vallari DS, Rafowicz A, Desai SM, Devare SG. Evidence for persistent hepatitis C virus (HCV) infection in hemophiliacs. Journal of Clinical Investigation 88: 1672-1679, 1991.

2. Alric L, Fort M, Izopet J, Vinel JP, Bureau C, Sandre K, Charlet JP, Beraud M, Abbal M, Duffaut M. Study of host- and virus-related factors associated with spontaneous hepatitis C virus clearance. Tissue Antigens 56: 154-158, 2000.

3. Alter MJ, Margolis HS, Krawczynski K, Judson FN, Mares A, Alexander WJ, Hu PY, Miller JK, Gerber MA, Sampliner RE, et al. The natural history of community-acquired hepatitis $\mathrm{C}$ in the United States. The Sentinel Counties Chronic non-A, non-B Hepatitis Study Team. New England Journal of Medicine 327: 1899-1905, 1992.

4. Barbosa AP, Martins RM, Teles SA, Silva SA, Oliveira JM, Yoshida CF. Prevalence of hepatitis C Virus infection among hemophiliacs in Central Brazil. Memórias do Instituto Oswaldo Cruz 97: 643-644, 2002.

5. Bassit L, Ribeiro-Dos-Santos G, Da Silva LC, Takei K, Villaca P, David-Neto E, Chamone D, Saez-Alquezar A. Genotype distributions of hepatitis C virus in Sao Paulo, Brazil: rare subtype found [letter]. Hepatology 29: 994-995, 1999.

6. Carmo RA, Oliveira GC, Guimaraes MD, Oliveira MS, Lima AA, Buzek SC, Correa-Oliveira R, Rocha MO. Hepatitis C virus infection among Brazilian hemophiliacs: a virological, clinical and epidemiological study. Brazilian Journal of Medical and Biological Research 35: 589-598, 2002.

7. Chan SW, McOmish F, Holmes EC, Dow B, Peutherer JF, Follett E, Yap PL, Simmonds P. Analysis of a new hepatitis $\mathrm{C}$ virus type and its phylogenetic relationship to existing variants. Journal of General Virology 73: 11311141, 1992

8. Choo QL, Kuo G, Weiner AJ, Overby LR, Bradley DW, Houghton M. Isolation of a cDNA clone derived from a blood-borne non-A, non-B viral hepatitis genome. Science 244: 359-362, 1989.

9. Colombo M, Mannucci PM, Carnelli V, Savidge GF, Gazengel C, Schimpf K. Transmission of non-A, non-B hepatitis by heat-treated factor VIII concentrate. Lancet 2: 1-4, 1985.

10. Davidson F, Simmonds P, Ferguson JC, Jarvis LM, Dow BC, Follett EA, Seed CR, Krusius T, Lin C, Medgyesi GA, et al. Survey of major genotypes and subtypes of hepatitis $\mathrm{C}$ virus using RFLP of sequences amplified from the 5 ' non-coding region. Journal of General Virology 76: 1197-1204, 1995.

11. Esteban JI, Esteban R, Viladomiu L, Lopez-Talavera JC, Gonzalez A, Hernandez JM, Roget M, Vargas V, Genesca J, Buti M, et al. Hepatitis C virus antibodies among risk groups in Spain. Lancet 2: 294-297, 1989.

12. Feinstone SM, Kapikian AZ, Purcell RH, Alter HJ, Holland PV. Transfusionassociated hepatitis not due to viral hepatitis type A or B. New England Journal of Medicine 292: 767-770, 1975.

13. Fletcher ML, Trowell JM, Craske J, Pavier K, Rizza CR. Non-A non-B hepatitis after transfusion of factor VIII in infrequently treated patients. British Medical Journal 287: 1754-1757, 1983.

14. Horowitz MS, Rooks C, Horowitz B, Hilgartner MW. Virus safety of solvent/ detergent-treated antihaemophilic factor concentrate. Lancet 2: 186-189, 1988.

15. Kernoff PB, Lee CA, Karayiannis P, Thomas HC. High risk of non-A non-B hepatitis after a first exposure to volunteer or commercial clotting factor concentrates: effects of prophylactic immune serum globulin. British Journal of Haematology 60: 469-479, 1985.

16. Kohara M, Tanaka T, Tsukiyama-Kohara K, Tanaka S, Mizokami M, Lau JY, Hattori N. Hepatitis C virus genotypes 1 and 2 respond to interferon-alpha with different virologic kinetics. Journal of Infectious Diseases 172: 934938, 1995.

17. Kuo G, Choo QL, Alter HJ, Gitnick GL, Redeker AG, Purcell RH, Miyamura T, Dienstag JL, Alter MJ, Stevens CE, An assay for circulating antibodies to a major etiologic virus of human non-A, non-B hepatitis. Science 244: 362-364, 1989.

18. Lanotte P, Dubois F, Le Pogam S, Guerois C, Fimbel B, Bacq Y, Gruel Y, Goudeau A, Barin F. The kinetics of antibodies against hepatitis $\mathrm{C}$ virus may predict viral clearance in exposed hemophiliacs. Journal of Infectious Diseases 178: 556-559, 1998.

19. Laskus T, Wang LF, Rakela J, Vargas H, Pinna AD, Tsamandas AC, Demetris AJ, Fung J. Dynamic behavior of hepatitis C virus in chronically infected patients receiving liver graft from infected donors. Virology 220: 171-176, 1996.

20. Le Guen B, Squadrito G, Nalpas B, Berthelot P, Pol S, Brechot C. Hepatitis $\mathrm{C}$ virus genome complexity correlates with response to interferon therapy: a study in French patients with chronic hepatitis C. Hepatology 25: 1250$1254,1997$.

21. Maisonneuve P, Laurian Y, Guerois C, Verroust F, Ferrer Le Coeur F, Courouce AM, Noel L. Antibody to hepatitis C (anti C 100-3) in French hemophiliacs. Nouvelle Revue Francaise D'Hematologie 33: 263-266, 1991.

22. Makris M, Garson JA, Ring CJ, Tuke PW, Tedder RS, Preston FE. Hepatitis C viral RNA in clotting factor concentrates and the development of hepatitis in recipients. Blood 81: 1898-1902, 1993.

23. Makris M, Preston FE, Triger DR, Underwood JC, Choo QL, Kuo G, Houghton M. Hepatitis $\mathrm{C}$ antibody and chronic liver disease in haemophilia. Lancet 335: 1117-1119, 1990.

24. Martins RM, Barbosa AP, Oliveira JM, Vanderborght B, Yoshida CF. Genotype analysis of hepatitis $\mathrm{C}$ virus in Brazilian hemophiliacs and blood donors. Vox Sanguinis 78: 255, 2000.

25. Martins RMB, Vanderborght BO, Yoshida CF. Hepatitis C virus genotypes among blood donors from different regions of Brazil. Mem. Inst. Oswaldo Cruz 93: 299-300, 1998.

26. Mauser-Bunschoten EP, Bresters D, van Drimmelen AA, Roosendaal G, Cuypers HT, Reesink HW, van der Poel CL, van den Berg HM, Lelie PN. 
Hepatitis C infection and viremia in Dutch hemophilia patients. Journal of Medical Virology 45: 241-246, 1995.

27. Mazur W, Mazurek U, Jurzak M, Wilczok T, Bulanowski Z, Gonciarz Z. Positive and negative strands of HCV-RNA in sera and peripheral blood mononuclear cells of chronically hemodialyzed patients. Medical Science Monitoring 7: 108-115, 2001.

28. McOmish F, Yap PL, Dow BC, Follett EA, Seed C, Keller AJ, Cobain TJ, Krusius T, Kolho E, Naukkarinen R, et al. Geographical distribution of hepatitis C virus genotypes in blood donors: an international collaborative survey. Journal of Clinical Microbiology 32: 884-892, 1994.

29. Okamoto H, Mishiro S, Tokita H, Tsuda F, Miyakawa Y, Mayumi M. Superinfection of chimpanzees carrying hepatitis $\mathrm{C}$ virus of genotype II/1 b with that of genotype III/2a or I/1a. Hepatology 20: 1131-1136, 1994.

30. Pasi KJ, Evans DJ, Skidmore SJ, Hill FGH. Prevention of hepatitis C virus infection in haemophiliacs. Lancet 1: 1474, 1990.

31. Perret BA, Senn M, Affentranger P, Poorbeik M, Burckhardt JJ, Morell A. [Seroprevalence of hepatitis C virus in hemophiliacs in Switzerland]. Schweizerische Medizinische Wochenschrift 123: 79-81, 1993

32. Pistello M, Ceccherini-Nelli L, Cecconi N, Bendinelli M, Panicucci F. Hepatitis $\mathrm{C}$ virus seroprevalence in Italian haemophiliacs injected with virus-inactivated concentrates: five year follow-up and correlation with antibodies to other viruses. Journal of Medical Virology 33: 43-46, 1991.

33. Pozzato G, Moretti M, Franzin F, Croce LS, Tiribelli C, Masayu T, Kaneko S, Unoura M, Kobayashi K. Severity of liver disease with different hepatitis C viral clones [letter]. Lancet 338: 509, 1991.

34. Rocha VG, Carmo RA, Murao M, Mourão JG, Ribeiro CMF, Martins MVCL, Viana MB. Predictive factors for the presence of hepatitis $\mathrm{C}$ virus antibodies in hemophiliacs: multivariate analysis. In: Resumo do Congresso da Sociedade Brasileira de Medicina Tropical, Salvador p. 368, 1994.

35. Rockstroh JK, Spengler U, Sudhop T, Ewig S, Theisen A, Hammerstein U, Bierhoff E, Fischer HP, Oldenburg J, Brackmann HH, Sauerbruch T. Immunosuppression may lead to progression of hepatitis $\mathrm{C}$ virus-associated liver disease in hemophiliacs coinfected with HIV. American Journal of Gastroenterology 91: 2563-2568, 1996.

36. Sambrook J, Fritsch EF, Maniatis T. Molecular cloning: a laboratory manual. Cold Spring Harbor Laboratory Press 3 New York, 1989.

37. Sarrazin C. Highly sensitive hepatitis C virus RNA detection methods: molecular backgrounds and clinical significance. Journal Clinical of Virology 25(supl 3): S23-29, 2002.

38. Sarrazin C, Teuber G, Kokka R, Rabenau H, Zeuzem S. Detection of residual hepatitis $\mathrm{C}$ virus RNA by transcription-mediated amplification in patients with complete virologic response according to polymerase chain reactionbased assays. Hepatology 32: 818-823, 2000

39. Schmidt WN, Klinzman D, LaBrecque DR, Macfarlane DE, Stapleton JT. Direct detection of hepatitis C virus (HCV) RNA from whole blood, and comparison with HCV RNA in plasma and peripheral blood mononuclear cells. Journal of Medical Virolology 47: 153-160, 1995.

40. Schmidt WN, Wu P, Cederna J, Mitros FA, LaBrecque DR, Stapleton JT. Surreptitious hepatitis $\mathrm{C}$ virus (HCV) infection detected in the majority of patients with cryptogenic chronic hepatitis and negative HCV antibody tests. Journal of Infectious Diseases 176: 27-33, 1997.

41. Schimpf K, Mannucci PM, Kreutz W, Brackmann HH, Auerswald G, Ciavarella N, Mosseler J, DeRosa V, Kraus B, Brueckmann C, et al. Absence of hepatitis after treatment with a pasteurized factor VIII concentrate in patients with hemophilia and no previous transfusions. New England Journal of Medicine 316: 918-922, 1987.

42. Silini E, Bono F, Cividini A, Cerino A, Bruno S, Rossi S, Belloni G, Brugnetti B, Civardi E, Salvaneschi L, et al. Differential distribution of hepatitis C virus genotypes in patients with and without liver function abnormalities. Hepatology 21: 285-290, 1995.

43. Simmonds P, Balfe P, Ludlam CA, Bishop JO, Brown AJ. Analysis of sequence diversity in hypervariable regions of the external glycoprotein of human immunodeficiency virus type 1. Journal of Virology 64: 5840-5850, 1990.

44. Simmonds P, Holmes EC, Cha TA, Chan SW, McOmish F, Irvine B, Beall E, Yap PL, Kolberg J, Urdea MS. Classification of hepatitis C virus into six major genotypes and a series of subtypes by phylogenetic analysis of the NS-5 region. Journal of General Virology 74: 2391-2399, 1993.

45. Sugitani M, Inchauspe G, Shindo M, Prince AM. Sensitivity of serological assays to identify blood donors with hepatitis C viraemia. Lancet 339: 1018-1019, 1992.

46. Toyoda H, Fukuda Y, Hayakawa T, Kumada T, Nakano S, Takamatsu J, Saito H. Presence of multiple genotype-specific antibodies in patients with persistent infection with hepatitis C virus (HCV) of a single genotype: evidence for transient or occult superinfection with HCV of different genotypes. American Journal of Gastroenterology 94: 2230-2236, 1999.

47. Troisi CL, Hollinger FB, Hoots WK, Contant C, Gill J, Ragni M, Parmley R, Sexauer C, Gomperts E, Buchanan G, et al. A multicenter study of viral hepatitis in a United States hemophilic population. Blood 81: 412-418, 1993.

48. Velasco M, Hurtado C, Brahm J. Anti-hepatitis C viral antibodies in different pathological entities in Chile. Revista Medica de Chile 118: 895-896, 1990.

49. Zein NN, Rakela J, Krawitt EL, Reddy KR, Tominaga T, Persing DH. Hepatitis $\mathrm{C}$ virus genotypes in the United States: epidemiology, pathogenicity, and response to interferon therapy. Collaborative Study Group [see comments]. Annals of Internal Medicine 125: 634-639, 1996. 